\title{
Charles Nodier, Dictionnaire raisonné des onomatopées
}

\author{
Lise Sabourin
}

\section{(2) OpenEdition}

\section{Journals}

\section{Édition électronique}

URL : http://journals.openedition.org/studifrancesi/6327

DOI : 10.4000/studifrancesi.6327

ISSN : 2427-5856

\section{Éditeur}

Rosenberg \& Sellier

\section{Édition imprimée}

Date de publication : 1 novembre 2010

Pagination : 563

ISSN : 0039-2944

\section{Référence électronique}

Lise Sabourin, «Charles Nodier, Dictionnaire raisonné des onomatopées », Studi Francesi [En ligne], 162 (LIV | III) | 2010, mis en ligne le 30 novembre 2015, consulté le 13 janvier 2021. URL : http:// journals.openedition.org/studifrancesi/6327 ; DOI : https://doi.org/10.4000/studifrancesi.6327

Ce document a été généré automatiquement le 13 janvier 2021.

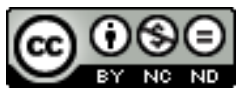

Studi Francesi è distribuita con Licenza Creative Commons Attribuzione - Non commerciale - Non opere derivate 4.0 Internazionale. 


\title{
Charles Nodier, Dictionnaire raisonné des onomatopées
}

\author{
Lise Sabourin
}

\section{RÉFÉRENCE}

CHARLES NODIER, Dictionnaire raisonné des onomatopées, édition établie, présentée et annotée par Jean-François JEANDILLOU, Genève-Paris, Droz, 2008, pp. 315.

1 Réfléchissant sur linguistique et esthétique bien avant les travaux du $\mathrm{xx}^{\mathrm{e}}$ siècle, d'une manière pour nous aujourd'hui surprenante, Nodier tente par ce dictionnaire de méditer sur les rapports entre bien dire et dire vrai en les fondant sur une généalogie de la langue. «La dimension sensorielle du lexique, l'inscription de la lettre comme gage d'historicité, le style en tant que manifestation esthétique consubstantielle à la langue et à la vie sociale» (Introduction, p. VIII) constituent ses trois critères d'analyse.

2 Nodier reprend, en les radicalisant ou en y répondant, certaines recherches de ses devanciers, Condillac et Rousseau, mais aussi Bernardin de Saint-Pierre et Pinot-Duclos, Bonald et les «casuistes du sens littéral». Pour lui, «toute langue est intouchable, moins parce qu'elle est transcendante et sacrée que parce qu'elle est humaine» (p. XII). Aussi s'intéresset-il aux parlers dialectaux pour leur transmission en ligne directe, leur ancrage territorial, leur manifestation orale. Il opte cependant pour une graphie historique plutôt que phonique pour conserver la raison de l'écriture des sons, restant attaché au concept de dégénérescence des langues au fil des âges, même s'il adopte une vision palingénésique à la Ballanche ou plutôt à la manière de Charles Bonnet, de «progrès par recréations successives» (selon l'expression de Paul Bénichou).

Ayant rencontré en 1805 l'avocat David de Saint-Georges, il entreprend ce dictionnaire des onomatopées, à partir de compilations de Nicot, Ménage, Court de Gébelin et du président de Brosses; mais la première parution en 1808 manque en fait de références que Nodier compense par une érudition acharnée pour la $2^{\mathrm{e}}$ édition qui comporte plus d'une centaine d'entrées supplémentaires, vingt ans plus tard, contemporaine de 
l'Examen critique des dictionnaires et des Notions élémentaires de linguistique. Il étend les onomatopées, au-delà du mimétisme des bruits élémentaires, humains, ruraux (d'animaux, notamment d'oiseaux, comme le montre le précieux commentaire de la Philomela d'Ovidius Juventinus, avec sa traduction française, pp. 237-281) et mécaniques, vers celles idiomatiques qui lui semblent concilier la figure ou l'aspect d'un objet avec son parcours logico-sémantique (liant par exemple le son de «cascade» au sens du latin cadere).

4 Cet ouvrage concernerait plus les linguistes si «son anachronisme foncier, sa validité à tout instant récusable» n'étaient compensés par une "pérennité fantasmatique fondée sur une quête romantique de l'absolu» (p.XXXII), malgré une démarche technique et métalinguistique plus que poétique ou ludique à la façon de Leiris ou Ponge. 